\section{MISS NIGHTINGALE ON THEORIES OF DISEASE}

To the Editor of THE LANCET.

SrR,-May I request the favour of space in your columns for the subjoined memorandum. The importance of the subject must be my excuse. Although very unwilling to appear before the public in the ungenerous character of a critic ${ }^{\circ}$ n what has fallen from the pen of Miss Nightingale, for whose writings, laboars, and public services I have the most unfeigned respect, the deep interest I feel in questions relating to the public health in India constrains me to contlovert what this eminent writer has placed on record in a public and official document, given to the world under the high sanction of the Minister for India. I feel this to be a duty all the more incumbent on me, because, in my official capacity, I was one of those who advised the Government of India to institute the inquiries into the origin and propagation of cholera, the utility of which Miss Nightingale has called in question. I think it right to add, however, that I alone am responsible for this criticism; $\mathrm{my}$ colleagues will see what I have written for the first time when it appears in your columns.

When Miss Nightingale has anything to say, it is said boldly in her own name. I feel, therefore, that it would be disrespectful and unmanly to criticise what has been thus written, either anonymously or under the cowardly shelter of a nom de plume. I therefore subscribe myself, Your obedient servant,

Royal Victoria Hoepital, Netley.

W. C. Maclean.

The Secretary of State for India in Council has just published a "Report on Measures adopted for Sanitary Improvement in India, from June, 1869, to June, 1870."

Miss Nightingale was asked to " say a few words on the present aspect of the work of sanitary improvement in British India," and this lady's "few words" are printed in the report.

In Section 2 of her paper Miss Nightingale thus expresses herself :- "Has not some uncertainty been thrown over the whole subject of Indian public health questions by intruding into it theories of disease? The intention is, of course, to obtain some central principle of action. But as no two people in search of such a principle ever probably arrived at the same, the general result of this method of dealing with public health questions is to amaze practical people, and to afford a good reason for doing as little as possible. The public health question is not a question of opinion. It is a question, 1 , of what is fact; 2 , of what is practicable and expedient? However ingenious a thing a theory may be, the wisest thing is never to expend public money on it. Are not the theories we have had, too, not of Indian produce, but of European manufacture? And have they anything whatever to do with public health problems? The questions to be dealt with are either questions of fact or they are nothing. No speculative matter should ever peep out of, or creep into, public health reports intended to lead to practical action."

Miss Nightingale has added a long note to this passage, in which she illustrates her meaning by a reference to the inquiry now being carried on in India on the fungoid theory of cholera, and the experimental trials on the "groundwater" theory of Professor Pettenkofer. Perhaps it will be better to give the ossential part of the note in Miss Nightingale's own words:-

"The Government has an inquiry instituted, and the first result is, that there are no special cholera fungi in India; the second, that cholera has assumed great intensity where there is no ground water at all. Others state explicitly that cholera excreta are the special foci of cholera. But then we find cholera spreading in great intensity where cholera excreta are dealt with in conformity with this theory, and not spreadir at all (as in the hospitals of Calcutta) where they have not been so dealt with. Another lass all the blame on cholera poison getting into water, unconscious, apparently, that cholera has committed ravages where no uch occurrence could possibly have taken place." "These," adds Miss Nightingale, "are but a few flowers from the garden of theories; but should these gardens be cultivated at all where the struggle with cholera is a dreadful, a too dreadful reality, and not a book theory?"'

Now on the above we have to observe that the investigation into the fungoid theory of disease was never intended to interfere, and in point of fact has not interfered, in the smallest degree with those measures of general sanitary reform which are detailed and commented on in the Report before us. Granting that, so far, the investigations of Drs. Lewis and Cunningham bave only given negative results, no one can doubt that the "theory of disense" put forward, after at least much painstaking labour and experiment, by the "German professor," was one worthy of being investigated; for had it proved to be based on fact, it would at once have solved a problem of the deepest in. terest to mankind at large, and in all probability have led to such measures as might have "stamped ont" the disease in its birthplace and most favourite home. Moreover, fre have no right to assume that, because the fungoid theory may prove to be a mistake, the searching inquiry into the mode of origin and spread of cholera in India now being conducted by the above-named gentlemen may not be productive of other results of importance both to the physician and to the sanitary reformer. The same is true of what is known as Pettenkofer's theory of "ground water" and its relation to cholera. It may not be true, it probably is not true to the extent supposed by the eminent man who conceived it, and supported it by arouments derived from much observation and honestly conducted inquiry and experiment; but it is even yet possible that this "theory of disease" may throw light on a fact not without interest, we may suppose, even to sanitary reformers of Miss Nightingale's school-viz., the oft-observed but as yet little understood fact, that this disease does frequently show a preference, so to speak, to certain places, which it sconrges, sparing others to all appearance neither better nor worse as regards ordinary sanitary conditions, but presenting differences of soil. With due deference to Miss Nightingale, we venture to think that this is a point worthy of being investigated by the cheap and simple methods parsued, which in no way interfere with the only measures to which Miss Nightingale attaches any importance.

Again, on the theory that "chol "... excreta are the special foci of cholera," we have to obser that there are many facts-and Miss Nightingale is all tor facts-which have a very important bearing on the at leaist occasional propagation of cholera in this way, and that those who advocate the disinfection and destruction of cholera excreta do not deserve to be put down as foolish theorists. What has been observed in the hospitals at Calcutta, and elsewhere in India, is, that the hospital servants, whose duty it is to remove the fresh excreta of cholera patients, do not suffer from the disease in an exceptional way. This is one "fact." But these same cholera evacuations, after they have undergone llecomposition, do become dangerous; and there is abundant evidence to prove that encamping grounds saturated with these discharges have in a great number of instances propagated the disease to healthy regiments using them; and the observations of such "theorists" as the late Dr. Snow, Dr. Budd of Bristol, Mr. Simon, and many other's, have established it as a fact beyond the reach of doubt or cavil, that cholera has again and again been propagated by the excreta of cholera sufferers mingling with the water consumed by healthy people. This is another "fact"; and we sulumit that those who desire to investigate it are worthy of praise, and not of the contempt which Miss Nightingale, in a public and oficial record, heaps on them.

In conclusion, let us observe that when Jenner noticed an eruption on the hands of cow-milkers, and the immunity from small-pox which they enjoyed, when he conceired the idea that some virus taken into the systems of the milkers exercised a protecting influence against a loathsome disease, then the terror of mankind, which, to use Miss Nightingale' words applied to cholera, was " a dreadful, a too dreadful reality," he, in fact, framed a "theory of diseaze." Yow, if Miss Nightingale be right, when Jenner proceeded to put his thecry to the test of experiment he was worthy of reprobation for applying his " theory of disease" to a public health question, instead of $\mathrm{I}$ aviag it to be dealt with by sanitary reformers in another age. In point of fact, he did the very thing now being attempted in India in the choler 
inrestigations, which Miss Nightingale, in the paper under rerien, does ber utmost to ridicule, to discourage, and to put domn, for no other reason that we can see than this, that those investigations, in some way not apparent to others, interfere with the large measures of sanitary reform now being carried out in India, and from some unexplained notion that the tendency of experimental inquiries by highly competent observers is, not to find some central principle of action, but to throw uncertainty over the whole subject of public health questions in that country.

\section{THE SURG ER O F T F E W A R. (FRON OUR SPECIAL CORIESPONDENT.)}

Having described as far as I can the hospital of the Anglo-American ambulance at Sedan, and its organisation, I shall proceed to do the same to the general nature of the wounds, and the modes of treatment usually adopted. Of course, having been able only to observe a small number of the cases, and that for a short time, it is impossible to give any statistically accurate information with regard to the wounds, or the result of their treatment; I can only mention such cases as I happened to notice, and give the general ideas which have been left on my mind. Doubtless a detailed account of the practice of this large hospital, including over 500 cases, will all be published in good time. The result of a very large number of the cases must, however, unfortunately remain unknown, as the Prussian authorities ordered the removal of every patient as soon as was possible, in many cases before any accurate idea could be formed of the ultimate result of the case. The removals were often made in common country waggons, without even straw for the patients to lie on, so that it is quite possible that cases going on well up to the time of removal may have taken a bad turn afterwards. All the patients in the hospital were French, and almost without exception were wounded at one of the last two days' fighting-that is to say, on August 31st, or September 1st. All the bullet wounds were, therefore, made either by the Bavarian rife or the needle-gun. The bullets of these two rifles are much the same in diameter, but different in shape, the Bavarian having a flat base, while that of the needle-gun is more the shape of an olive. They are both considerably larger than the chassepot bullet. The course of the bullet in most of the cases $I$ saw had been very straight, and the bones in its path were usually fearfully shattered and fissured, often to a great distance from the seat of injury. In fact, the wounds agreed exactly with the ordinary descriptions of rifle wounds in modern works on military surgery. Besides bullet wounds there were a considerable number resulting from fragments of shell. Those made by the smaller pieces differed but little from bullet wounds in appearance and results, but the large fragments produced far more terrible effects. In one ward. I saw two poor fellows with almost exactly similar wounds. Each had been struck by a fragment of shell in the loins and gituteal region. The shin, erector sping, and gluteal muscles were divided, laying bare part of the sacrum and last lumbar vertebra in one case; and in both a large piece of the outer surface of the os innominatum, which in one case was fissired in all directions, and driven in towards the carity of the abdomen. The whole formed a gaping wound afout ten inches in length by five wide. I saw these twi men up to one month after the injury; one was then sickening with pyæmia, but the other seemed progressing weil, and the wound was granulating healthily. I saw another peculiar shell-wound in which the right eyeball hat been completely destrored without injury to lids, the onls wound visible externally being a small scratch on the cheer.

At the time I first saw the patients, wounds of the lungs, head, or abdomen were not common, most having perished, I surpose, before my arrival. Wounds of the extremities formed the greater part of the cases, and a clear majority of all wounds were of the lower extremity. I had the oppritunity of watching one very iuterestiur case of wound of the chest in a young Alsatian who had been struck by a bullet on the right clavicle. The ball was extracted from under the skin in the right interscapular region, opposite the spine of the scapula. Some tine after a fragment of the clavicle, more than three-quarters of an inch in length, and consisting of nearly half the taickness of the bone, was removed from the same wound, having completely traversed the lang with the bullet. Air escaped freely from the wound on coughing, fet there was no general plenrisy or pneumothorax, the only physical signs being thuse of consolidation of the upper part of the lung, and the discharge scarcely moistened the dressing. He was soon afterwirds removed by the Prussians, in apparently good health, to some other hospital. This was of course a rare excertion, and contrasted favcurably with the case of another patient, a Zouave, wounded in much the same part of the lung. This poor fellow was suffering from pneumothoras, and fetid suppuration in the pleura, the discharge being enormous, amounting to about two pints daily, all proceeding from a wound which would scarcely admit the nozzle of a springe. This man survived over a month, and at last died from exhaustion.

Of wounds of the head I saw none of particular interest, as I suppose I was too late. 'There was, however, a very remarkable case of wound of the spinal cord, about the region of the fifth cervical vertebra, causing paral ssis of the whole body beiow the wound except the richt arm, the respiration being entirely abdominal. In this stiote he lived for nearly three weeks, when pneumouia and exhaustion put an end to his misery. I regret to state that I believe no postmortem examination of the body was made.

In the upper limb wounds of the juints were very common, especially of the elbow. I saw cre also of the wrist, the ball having passed laterally, enteriug just below the styloid process of the ulna, and making its exit on the palmar surface, near the ball of the thumb, shattering all the small bones of the wrist on the inner side of the carpus. Most of the fragments were removed by degrees as they became loose, and in spite of considerable burrowing of pus both upwards and downwards, there seemed every prospect of saving the hand.

In the lower limb many primary ampatations had been performed by the German surgeons, and a considerable number of these were alive when I joined the hospital. It was curious to contrast the usually healthy look of these men with the miserable appearance of those on whom conservative surgery had been practised. Wounds of the knee were frecuent, and in many cases attempts had been made to save the limb; but, as far as I know, these all resulted in excision or secondary amputation. There was also a considerable number of simple flesh wounds of the thish, some penetrating, and some not. These were always accompanied by most profuse suppuration, frequentiy burrowing among the intermuscular spaces. I sarr none of these die, but some were brought very low, especiully when they also suffered from diarrhca or dysentery. Conservative surgery in bullet fractures of the bones of the leg seemed very fashionable, but $I$ am afraid met with little success where both bones were fractured. I saw one interesting case, in which the bullet had punched a elecri hole through the tibia from side to side, leaving the fibula minjured. In front and behind the hole, the bone ras spliutered into several fragments, but they were all in normal position, remaining attached to the periostenm. Fragments of the cancellous tissue continued to come away at each dressing for the first two weeks, but the discbarge was very slight, and when I saw him last he was in a fair way to recover.

Almost all the wounds of every part were accompanied by most prof use suppuration, caused by the depth of the wounds, and consequent accumulation of pus in the deep parts. The discharge was in every case more or less fetil, as the means adopted failed to prevent putrefaction in the deep parts of the wound, although disirfecting the pus when it escaped. In some cases the fotor was horribie, and the pus caused most unpleasant sores on the hands whenever it came in contact with a raw surface, sucresting forcibly the dangerous amount of irritation half it pint of such pus must cause when pent up and burrowing in the deep parts of a limb. 